\title{
COMMUNITY-LED PLANNING: THE KEY TO SUCCESSFUL SLUM UPGRADING?
}

\author{
Ráhel CZIRJÁK ${ }^{\mathrm{a}}$ \\ a Pallas Athene Innovation and Geopolitical Foundation, czirjak.rahel@paigeobudapest.hu
}

Cite this article: Czirják, R. (2019). Community-Led Planning: The Key to Successful Slum Upgrading? Deturope, 11(1), 164-181.

\begin{abstract}
As a result of the urbanization crisis taking place in the developing world, nearly a quarter of the Earth's urban population lives in slums (WUP, 2014), amounting to a total of 881 million people in the developing countries in 2014 (UN-HABITAT, 2016). Without effective intervention, these figures are expected to increase in the future, since the urban population of the developing countries will have risen by almost 1 billion people by 2030 (WUP, 2018). Slum upgrading is therefore an area of paramount importance that is realized in practice by taking one of two approaches: one of the most common procedures is external or expert planning, when identifying the problem and developing and implementing a solution is done by experts. In the case of the other approach, these steps are realized by members of the given community with a facilitator - this is called community planning. This paper compares these two planning approaches using two slum upgrading programs in Kenya as examples, and it aims to use the experiences gained from them to support the hypothesis that the key to efficient slum upgrading is the active involvement of the affected community in the planning process; that is, community planning.
\end{abstract}

Keywords: Community, Community planning, Expert planning, Slum upgrading, Urbanization crisis, Africa, Kenya

\begin{abstract}
Absztrakt
A fejlődő világban tapasztalható urbanizációs válság következtében napjainkban a Föld városi lakosságának csaknem negyede nyomornegyedlakó (WUP, 2014), ami a fejlődő országokban összesen 881 millió föt jelentett 2014-ben (UN-HABITAT, 2016). Hatékony beavatkozás nélkül pedig a jövőben ezen számok növekedése várható, ugyanis 2030-ra a fejlődő országok városi lakossága további, közel 1 milliárd fővel fog bővülni (WUP, 2018). A nyomornegyedfejlesztés tehát egy kiemelkedő fontosságú terület, mely a gyakorlatban kétfajta megközelítés mentén valósul meg: az egyik legelterjedtebb eljárás a külső, vagy szakértői tervezés, melynek során a problémafeltárást, megoldás kidolgozását és megvalósítást szakértők végzik. A másik megközelítés esetén ezeket az érintett közösség tagjai valósítják meg, egy facilitátor segítségével - ezt nevezzük közösségi tervezésnek. Jelen tanulmány e két tervezési megközelítést hasonlítja össze két kenyai nyomornegyedfejlesztési program példáján, melyek tapasztalatai alapján igyekszik alátámasztani a hipotézist, ami szerint a hatékony nyomornegyedfejlesztés kulcsa az érintett közösség aktív bevonása a tervezési folyamatba, vagyis a közösségi tervezés.
\end{abstract}

Kulcsszavak: Közösség, Közösségi tervezés, Szakértői tervezés, Nyomornegyedfejlesztés, Urbanizációs válság, Afrika, Kenya

\section{INTRODUCTION}

Slum upgrading is most often implemented in the context of international development cooperation, for local authorities usually have insufficient capacities for intervention. It is 
therefore worth contextualizing how the participation of those affected appears in the narrative of international aid.

The emphasis and keywords of the international aid system, created and institutionalized after World War II, have gradually changed over the decades, mainly due to shifts in global politics and the global economy (Czirják, 2017). Ownership and the principle of partnership appeared among international aid's keywords during the decade following the dissolution of the bipolar world order, and it meant that recipient countries could play a more active role in planning and implementing aid (Paragi et al., 2007).

The principles of international development cooperation formulated since the turn of the millennium are evolving similarly to the 1990s, with further emphasis on ownership and partnership (Szent-Iványi, 2009). This means that in the 21st century it is increasingly important that recipients affected by the given problems actively participate in seeking solutions by developing their own strategies and operative programs.

This is reflected, for example, in OECD's 2005 Paris Declaration, which emphasizes the importance of the ownership approach, meaning that partner countries are obliged to come up with their own development strategies, divide them into operative programs, and play a leading role in coordination during aid implementation, too (OECD 2005).

The above might give the impression that involving those affected in problem-solving, that is, participation is the "invention" of the last two or three decades; however, its roots go back much further. The concept of participation was introduced to development professionals by Pedagogy of the Oppressed, a book written in the 1960s by Brazilian educator and philosopher Paulo Freire, which in the late 1980s and early 1990s led to the emergence of several practical models for the active involvement of recipients in development (Ciurlik, 2013). Through emphasizing the importance of partnership and ownership, participation eventually became part of the broad discourse of international aid in the 1990s and 2000s.

If we examine the practical realization of these keywords, we can conclude that based on the agents involved in the process, we can distinguish two main kinds of development activities: expert-led (also referred to as external planning) and community-led or participatory planning (internal planning). Despite the fact that inclusion, partnership and ownership approach have become key terms of developmental discourse, the expert-led planning remains the most common method of international development cooperation.

This paper compares these two planning procedures first theoretically, then through two slum upgrading programs realized in Kenya: the Kenyan Slum Upgrading Programme in Kibera (as an example of expert-led planning) and the Building in Partnership: Participatory Urban Planning in Kitale (as an example of community planning). 
According to our hypothesis, the key to efficient slum upgrading is the active involvement of the affected community, that is, community planning. The hypothesis will be justified or disproved on the basis of the comparative analysis of the two slum upgrading programs.

\section{COMMUNITY AND EXPERT-LED PLANNING - THE TWO WAYS OF SLUM UPGRADING}

The traditional method of planning an upgrading activity is external or expert-led planning, during which program-related research is conducted and information is collected by an expert or a team of experts. During this exploratory work to obtain information, the affected people in this case the slum residents - may be asked (in interviews or questionnaires), but they are not actively involved. The whole process is driven by experts who develop plans, and the affected people only have temporary and limited access to information (Sain, 2010). Consequently, they are informed about the final result of the planning only at the end of the process, when the final form of the plan takes shape, or even later, during the implementation of the intervention. Therefore, the persons affected do not play a substantial role in the developmental solutions.

One of the definite advantages of this procedure is that due to the limited number of agents (or at least fewer than in community planning), the process is relatively fast and more predictable both in terms of time and costs. During the planning procedure, the experts attempt to draw up a plan in accordance with the client's demands and the professional requirements (Sain, 2010). Despite this, however, this approach has a pitfall: the experts' position and approach. As outsiders, they can hardly get a realistic picture of the problem merely from indirect data sources, even if the relevant people are interviewed or they fill in questionnaires regarding certain issues. Even in this case, experts remain outsiders who, as result of their position, cannot see the given problem the same way as the beneficiaries of the intervention. Consequently, it is rather improbable that the solutions offered will address the ideas and actual needs of the people affected.

Another drawback of this method is that the external approach might have a negative influence in the long term. This procedure is based upon the shortage model, that is, it examines what needs the given communities have and tries to satisfy them from external sources - this is what international development cooperation traditionally does. As a result, a servicing environment is generated, where the people in need receive aid and become passive dependents of the donors. They see themselves as victims of the system and do not become active. This approach is unable to actually solve the given problem, and after the termination of the aid, the community will be even worse off than before.

Besides external planning, the other approach is internal or community planning, which aims to address and activate the parties involved, survey their situation through their participation, 
develop a solution/solutions to improve their state, and, if possible, have the solution(s) implemented by the community (SURE, 2012). This means that the relevant people get actively involved in the developmental process already from the initial phase and are not informed about the results only at the end of the planning. A solution-oriented plan, usually based on a consensus, is developed as a result of common thinking. As the plan is created by the relevant parties, it reflects their needs and potential utilizable for the development, and thus the intervention can offer a solution to the actual problems in accordance with the local conditions. Furthermore, since the people affected draw up the plan themselves, they feel that it is their own, which guarantees successful implementation and future sustainability (Sain, 2010).

Experts are also involved in the community planning process as facilitators. The facilitator is responsible for aiding the process, which means they coordinate and assist the activity of the community from the background (Bardóczi and Giczey, 2010). The facilitator asks questions during the planning process and the answers reveal the problems to be solved, the opportunities, developmental ideas etc. The facilitator is therefore not responsible for outlining actual proposals for solutions; their role is to motivate collective thinking (Bardóczi and Giczey, 2010).

Furthermore, the active participation of the relevant community in the planning process might have further advantages. First, it might considerably improve the quality of the plans and thus the efficiency of the development interventions - because the people affected have expressed their needs. Therefore, the solutions focus on the actual problems; they are not distorted and do not result in a different focus or emphasis in the plans.

In addition, community planning channels the capacities and capabilities of the local community, because the suggested proposals are partly or entirely built on the internal resources of the affected people. It is therefore not solely the decision-makers (donors) who have to commit time, money and energy resources, but the invested resources and decision-making responsibilities are divided among the agents of the process (Paul, 1989).

This is beneficial both to the donor and the beneficiary community, because they take part in the process as active and effective participants. Internal planning therefore has a value-based approach (Sain, 2010), as opposed to the shortage model of expert planning. Internal planning focuses on the resources, capacities and internal values of the affected community, and attempts to draw up solutions based on them, with the active participation of the community. Thus, after the external agents (donors) finish their activities, the community will be influential, active, able to take responsibility for its own living conditions and formulate them in the long term, too.

Due to its value-based approach, its effective use of internal resources and its special characteristics, the community planning process is a joint learning process (Sain, 2010) during 
which the values and knowledge of the stakeholders are explored and plenty of new competences acquired, from team work through the articulation of interests to communication. This, in the long term, might enhance the efficiency of the community in solving its own problems.

Nevertheless, similarly to expert planning, community planning also has its disadvantages. The active participation of the people involved makes internal planning a multi-agent process, which might result in several negative aspects. The process fundamentally aims to develop a consensus-based solution, but the large number of agents implies various interests, which increases the chance of conflicts; therefore, arriving at a solution that is acceptable to everybody takes more time than expert planning (Sain, 2010). The pace and direction of the planning procedure itself largely depends on the people involved - their capacities, inclination to participate, etc. Consequently, it is hard to plan the process in terms of schedule and potentially costs as well.

Furthermore, it is important to note that there is no empirical study that unambiguously proves that the results of community planned projects outperform interventions planned by experts (Jeffrey, 2003). This is because the process might reduce the efficiency of decisionmaking, since the solution that is acceptable to all may be suboptimal in terms of the problem to be managed (Beke and Jávor, 2013).

Table 1 Strengths and weaknesses of external and internal planning

\begin{tabular}{|c|c|c|}
\hline & Strengths & Weaknesses \\
\hline External planning & $\begin{array}{l}\text { ease of decision-making } \\
\text { (number of participants } \\
\text { and time) } \\
\text { predictability (in time and } \\
\text { cost) }\end{array}$ & $\begin{array}{ll}- & \text { frequent misdiagnosis } \\
- & \text { lack of ownership (passive } \\
\text { dependency) }\end{array}$ \\
\hline Internal planning & $\begin{array}{ll}- & \text { better diagnosis of the } \\
\text { problem } \\
- & \text { ownership (responsibility) } \\
- & \text { distribution of invested } \\
\text { energy and responsibility } \\
-\quad \\
\text { enables members of the } \\
\text { community (new skills and } \\
\text { capabilities) } \\
\text { - empowers members of the } \\
\text { community (active and } \\
\text { powerful community) }\end{array}$ & 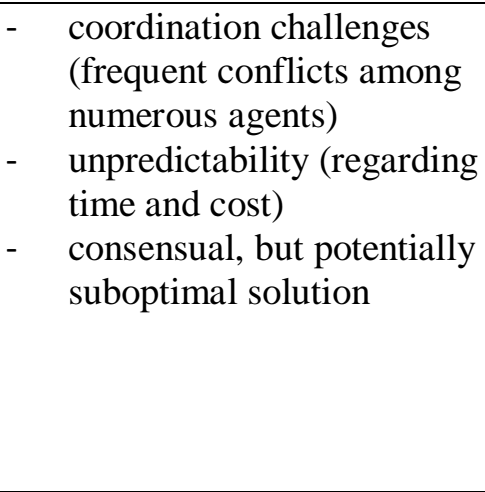 \\
\hline
\end{tabular}

Source: own elaboration

The advantages and disadvantages of the two planning processes are indicated in Tab. 1 . Comparing the two methods, we can draw the following conclusions: one cannot categorically say that either procedure is better or worse. The selection of the preferred method always 
depends on the given situation and problem to be solved. In cases when immediate intervention is required - for instance, in the case of humanitarian disasters-, expert planning might be the better solution thanks to its rapidness. Regarding slum upgrading, however, the aforesaid analysis suggests that community planning is the ideal procedure, because it leads to the development of solutions that react to the actual problems and fit the local conditions. In addition, this occurs with the participation of the local inhabitants, which creates ownership and ensures a more sustainable solution in the long term. Furthermore, the greatest advantage of community planning is that it enables and empowers the relevant people, through which the (successful) planning process transforms them into members of an influential and active community that is capable of managing their lives after the donors leave.

To support this hypothesis, two Kenyan slum upgrading programs will be presented in the following section.

\section{THE CONTEXT OF DEVELOPMENT INTERVENTIONS: URBANIZATION CRISIS IN AFRICA}

Modern urbanization started with the industrial revolution, which created the conditions that enabled faster and more large-scale urbanization (Kovács, 2002). Until the second half of the 20th century, this process had been an indicator of economic development due to the strong correlation between GDP per capita and the urbanization rate until the 1960s and 1970s (Kovács, 2002). However, during this period the focus of urbanization shifted to the decolonized developing countries (Kovács, 2002), which saw the beginning of a population growth so rapid that neither urban infrastructure expansion nor economic growth could keep up with it. The speed of this boom is such that "the public service, housing and traffic supply cannot keep pace with the increasing demand, and the formal labor market cannot absorb the crowds flowing into the city" (Ricz, 2009), therefore the urbanization of the developing world can be defined as an urbanization crisis. Africa, the fastest urbanizing continent on the planet, demonstrates this clearly: urban population increased more than sixteenfold between 1950 and 2014, from 33 million to 547.6 million people. By the middle of the $21^{\text {st }}$ century, their number might reach 1.5 billion (WUP, 2018).

The most striking symptoms of the urbanization crisis are slums, in which nearly a quarter of the Earth's urban population lives. This amounts to 881 million people in the developing countries (UN-HABITAT, 2016). Compared to the world average, the situation is worse in SubSaharan Africa, where over half of the urban population (56\%) lives in slums. This ratio may 
even increase in the future, since the urban population of the developing countries will increase by nearly 1 billion people between 2018 and 2030 (WUP, 2018) - efficient solution procedures are therefore urgently needed.

The direct developmental context of the two case studies to be described below is Kenya, where urbanization has been increasing since the declaration of independence in 1963. While in the mid-1960s every twelfth person lived in cities and towns, today more than every fourth citizen is urban (WUP, 2018). According to the UN's forecast, the rate of urban dwellers within the total population might reach 46 per cent by the middle of this century (WUP, 2018).

In the beginning, urban population was concentrated in the two largest settlements of the country: in 1963 around $70 \%$ of the urban population lived in the capital city of Nairobi and Mombasa, the most significant harbor city of the country (Majale, 2009). However, their predominance within the settlement network has been decreasing for decades, and in 2018 they accounted for "only" about 38 per cent of Kenya's urban population (WUP, 2018). This shows the rapid growth of small towns with less than a million inhabitants.

Urbanization will remain a dynamic process in Kenya in the future. Although growth will slow over time, it will still remain considerable: the current $4.23 \%$ annual average growth of town-dwellers will have decreased to $3 \%$ by 2050 (WUP, 2018). This will still amount to an inflow of huge crowds to the urban regions of Kenya (due to migration and natural growth), presenting further challenges to urban planning and management. This population growth rate already exceeds the capacity of city management, therefore in Kenya - in accordance with the Sub-Saharan African average - 56 per cent of the urban population is forced to live in slums (UN-HABITAT, 2016). The developments presented below attempt to remedy this situation.

\section{The two methods of the planning procedure: KENSUP and BiP:PUP in Kenya}

Following the theoretical introduction, I will now present the implementation of the Kenya Slum Upgrading Programme (KENSUP) in Kibera as an example of external planning, and the Building in Partnership: Participatory Urban Planning (BiP:PUP), a slum upgrading program realized with community planning in Kitale.

The case studies were selected on the basis of the following factors: Kibera, located in the capital city of Kenya, is considered the largest slum in Africa, therefore it receives considerable attention from the press, developmental agencies and non-profit organizations. As a result of this, plenty of accounts about life here are available, which are supplemented with interviews, conducted by the author, with volunteers and development professionals who have been to Kibera. 
Czirják, R.

The BiP:PUP program realized in Kitale is referred to by international literature as a good example of community slum upgrading, with a well-documented methodological background. The two programs are comparable because both were carried out in Kenya, in identical historical, social, economic and legal environments. Nevertheless, it should be noted that the population of the two slums is different, which is a disadvantage when comparing the programs.

\section{Handling the problem of slum upgrading in Kibera: KENSUP}

Kibera is situated $5 \mathrm{~km}$ southwest from the central business district of Nairobi and covers an area of $2.5 \mathrm{~km}^{2}$ (Warah, 2007). It is hard to define the exact size of its population: various sources estimate it to be between 170,000 and 1 million people (MKP, 2018; Keserü, 2010: 70; Davis, 2006; UN-HABITAT, 2007a).

The vast majority of the buildings in the slum are mud huts with tin roofs, usually jointly rented by several tenants (Keserü, 2010). The whole district lacks basic urban infrastructure: there is no piped drinking water, sewage system, waste disposal or electricity (UN-HABITAT, 2010). Furthermore, the slum is overcrowded, therefore public hygiene is extremely poor: surveys conducted by healthcare organizations show that half of the inhabitants can be diagnosed with malaria, cholera, typhus or other serious viral diseases, and 40 per cent of children do not survive beyond their fifth birthday (Solymári, 2012).

In 2001 the UN-HABITAT initiated the Kenya Slum Upgrading Program (KENSUP), which aims to improve the living conditions of the citizens living in Kibera and other slums of Nairobi. The program applies a multidisciplinary, integrated approach to slum upgrading, which means that during its implementation, attempts were made to develop basic infrastructure such as water and public hygiene services, generate incomes for the slum-dwellers, implement governance that considers the interests of the poor, improve housing, ensure ownership and develop physical and social infrastructure (UN-HABITAT, 2007b).

KENSUP is based on the extensive partnership between the UN-HABITAT, the Kenyan government, the local authorities, the communities involved, non-profit organizations and the private sector. It should also be highlighted that the program is basically top-down (MacPherson, 2013), meaning that the decisions related to the development intervention were made by the UN without the involvement of the local inhabitants.

KENSUP was started in 2004 in five settlements of the country (in Nairobi, Kisumu, Mavoko, Mombasa and Thika) as part of eight projects. Three of these projects refer to Kibera: the Kibera Slum Upgrading Initiative, the Kibera Integrated Water, Sanitation and Waste 
Management Project, and the Youth Empowerment Programme. The following section focuses on the Kibera Slum Upgrading Initiative (UN-HABITAT, 2008).

The implementation phase of the Kibera Slum Upgrading Initiative started in 2012 (Anderson and Mwelu, 2013), when one of the districts of Kibera (Soweto East) was divided into four zones (A, B, C, D) for the purpose of systematic reconstruction (Jones, 2015). While huts are demolished and houses built in a zone, their inhabitants are placed in temporary accommodation until their new houses are completed (Scruggs, 2015). The slum's former tenants can buy the one-, two- or three-room apartments below market value, for $\$ 5,000-11,250$ (Anderson and Mwelu, 2013).

However, during the implementation of the development, structural problems arose, fundamentally questioning the success of the intervention. The affected people feared not being able to pay the costs of the new apartments, since they had to pay for public services established here, but the program generated no additional income for them. Since then these fears have turned out to be justified (Minja, 2017).

As a kind of management of the problem, and as an exploitation of the economic "opportunity" created by the development, it can be observed that the inhabitants of Kibera often move back to other districts of the slum and rent out their newly-built apartments more expensively (Jones, 2015). Although this generates additional income for them, it is not a solution to the problem of slums. Therefore, the results of KENSUP cannot be considered an obvious success.

The local inhabitants did not participate in the planning of the project - despite the keywords "partnership", "participation" and "involvement" in the project documentation -, so their actual needs could not be revealed. They were only informed about the aspects and realization method of KENSUP, which, as the UN put it, meant "sensitization" realized as part of "social mobilization actions", during which the inhabitants were informed about slum upgrading (MacPherson, 2013). This means that only the lowest level of social involvement, informing the residents was realized during the program.

Therefore, this approach is unable to manage the problem of the local people, and it seems that the investment could not solve the problem of housing for the poorest. Instead of improving the living conditions of the locals, the building projects have most likely worsened them.

We believe that two - basically pessimistic - scenarios seem to be realistic. According to the first version, the new houses result in gentrification in Soweto East, thus the original inhabitants will not only not get a decent home, but their original living space will significantly decrease owing to the new housing districts. As a result, they will have no other choice than to 
move to another place, losing contact with the well-known local community, which functions as a safety net.

According to another possible scenario, even if it is really the previous citizens of Soweto East who move into the new apartments, these apartments will sooner or later be in a similarly poor condition as the other parts of the slum, because there are insufficient resources for the maintenance and development of the properties. Although in this case we can speak about some improvement in infrastructure terms - as the new stone houses are better homes even in this poor state than the tin-roofed mud huts -, the breaking up of the local community due to being moved apart might result in negative social and economic effects that the project managers could not foresee.

Overall, this element of KENSUP is a project realized in a wide-ranging partnership, elaborated and implemented with external planning. Although it tried to react to the needs of the beneficiaries, it failed due to being controlled by external actors, since it proposed solutions to problems that lacked the observations of those affected. These proposals - as it turned out during their implementation - did not solve the problems, and even made them worse.

\section{Community planning in Kitale: BiP:PUP}

The second case study is about the Town of Kitale, situated northwest of the Kenyan capital city and functioning as the administrative and economic center of Trans-Nzoia District, Rift Valley Province. In the settlement of over 200,000 inhabitants, 65\% of citizens live in slums (Majale, 2009), their living conditions being similar to those in Kibera. In this region that is suitable for agricultural production, a large migration flow has started from the rural areas into the cities and towns because drought and decreasing economic opportunities offered by farms made subsistence impossible for locals (Chege and Majale, 2005). As the center of the district, Kitale is particularly affected by this process, and its local government is powerless and its capacities insufficient for appropriate planning and management to keep pace with the growth of the city.

In order to improve the slums in the city, the UK DFID (Department for International Development) initiated a program entitled Building in Partnership: Participatory Urban Planning, realized between 2001 and 2004. The overall aim was to "enhance the efficiency of the city's operation and the local governmental planning", which in practice means the introduction of the partnership approach in urban planning so that poor men, women and children, as well as community-based organizations and public and private institutions might 
take part in this process, and developments that are sustainable in the long run in economic, social and environmental terms might be implemented (Majale, 2009).

Focusing on the elaboration of the Local Authority Service Delivery Plan (LASDP), the BiP:PUP formed an integral part of the management and planning system of the Kenyan settlement. It is the document the local governments have to draw up to receive central governmental funds. In principle, this document is to be prepared during a structured annual cycle with participatory planning; nevertheless, this process is generally ad hoc, policy-oriented and non-transparent, so the aspects and needs of the poor cannot be considered and integrated in the developmental documents as they lack appropriate influence and power to enforce their views in this unequal process (Chege, 2006).

The BiP:PUP attempted to change this situation by realizing participatory planning with an appropriate methodology during a transparent process, within the institutional framework of the existing public administrational system.

As the first step of the process, the local government conducted settlement-level public opinion research to find out about the main issues in the city and help the local communities to identify and map their development needs (Chege and Majale, 2005). During this survey a „participation inventory” was also prepared, including the potential partners of the project (Chege, 2006).

As the following step, consultations based upon the results of the general opinion research were started in twelve election districts in order for the residents to rank the intervention areas by mutual consent. As a result of this process, three intervention areas of the project were chosen (the slums of Tuwan, Kipsongo and Shimo la Tewa), where the neighborhood plans were elaborated and implemented with community planning (Majale, 2009).

This project was realized with the cooperation of over twenty agents, including public administrative, church and non-profit organizations, researchers, grassroots groups and private sector agents. The implementation and management of the BiP:PUP was the responsibility of the Intermediate Technology Development Group-Eastern Africa (ITDG-EA), a non-profit organization providing technical assistance in the fight against poverty (ITDG.org), in cooperation with numerous other partners - including the local government of Kitale -, while the overall management was the task of the UK Department of ITDG (Chege and Majale, 2005).

Due to limitations of space, only the development realized in one of the three slums is presented here. 
Czirják, R.

\section{Tuwan}

With nearly 65,000 inhabitants, Tuwan is the largest slum in Kitale. Most local homes are made of wattle and daub, covered with tin roofs - like in Kibera. Before the project's implementation, the public hygiene situation was largely similar to that in Nairobi, described above; like in Kibera, it was also difficult to access healthy drinking water in Tuwan. There was no access to clean drinking water in the slum and the local sources were contaminated, imposing significant health risks; there were no appropriate toilets or bathrooms either, which led to the widespread use of "flying toilets" (Majale, 2008), meaning toilets were replaced with plastic bags, thrown away after use.

In cooperation with ITDG and the local government of Kitale, the residents of the slum created the Tuwan Neighborhood Plan as part of community planning, as well as the Strategic Action Plan for the practical implementation of the development identified in the neighborhood plan (Majale, 2009). The planning process was related to the town's above-mentioned LASDP process, therefore the development could be implemented in partnership with the local government and the relevant community (Chege and Majale, 2005).

The local citizens identified as a priority of development the establishment of a sanitation center to handle public hygiene problems. This center is a two-story building with separate bathrooms and flush toilets available for men and women. In addition, a laundry and a multifunctional room have also been established to provide consultation and screening examinations for residents as a HIV/AIDS center (Majale, 2008).

The construction site was offered by the local government of Kitale, and the local inhabitants were involved in both the planning and the building works. They were acquainted with various alternative building technologies, which proved to be a considerable cost-reducing factor. The sanitation center is a closed and environmentally friendly system recycling both sewage water and methane. Water is heated with the resulting gas and sewage water is used as manure in the pot garden operated by a group of local women. These solutions promote local efficiency by reducing the operational costs and generating income (Majale, 2008).

Economic sustainability is also facilitated by the fact that the inhabitants have to pay a small amount of money for the infrastructure services. An elected committee is responsible for the operation of the center (Majale, 2008).

In Tuwan the local inhabitants could participate in the planning process of the local government (LASDP), and the ideas generated this way have partly been realized through the partnership relation. An important aspect of the process was that the construction works were 
carried out by the affected people themselves. This way they acquired new knowledge (about the building technique, as well as organizing and coordinating the process, etc.) and the successful implementation made them feel more self-confident (Majale, 2008); on the whole, their acting and entrepreneurial capacity developed, which greatly advances their later prosperity. This is the most important benefit of community planning.

\section{A comparison of KENSUP and BiP:PUP}

In the following, the two slum upgrading programs are compared on the basis of the aspects below:

Table 2 A comparison of KENSUP and BiP:PUP

\begin{tabular}{|l|l|l|}
\hline Aspects & KENSUP & BiP:PUP \\
\hline Initiating actor & External: UN HABITAT & $\begin{array}{l}\text { External: Department of } \\
\text { International Development } \\
\text { (UK) }\end{array}$ \\
\hline Aim of program & Improving living conditions & $\begin{array}{l}\text { Enhancing the effectiveness of } \\
\text { city and municipal planning }\end{array}$ \\
\hline Definition of the problems by & $\begin{array}{l}\text { Affected residents (local } \\
\text { community) }\end{array}$ \\
\hline Level of social involvement & Informing (external planning) & $\begin{array}{l}\text { Partnership articipatory } \\
\text { planning) }\end{array}$ \\
\hline Nature of intervention & $\begin{array}{l}\text { Complex: mainly } \\
\text { infrastructural soft } \\
\text { elements) }\end{array}$ & $\begin{array}{l}\text { Complex: infrastructural and } \\
\text { soft elements }\end{array}$ \\
\hline Sustainability & Questionable ecologically, \\
\hline Long-term social influence & Rather negative & $\begin{array}{l}\text { Economically, } \\
\text { socially sustainable }\end{array}$ \\
\hline
\end{tabular}

Source: own elaboration

A program is considered successful if it offers a real solution to the problems defined by the local community, the intervention is sustainable both in economic and political terms, and thus the invested resources are exploited appropriately.

Based on the aspects of the examination, we can establish the following about the UN KENSUP program: the developmental program was initiated by an external institution, i.e. the UN-HABITAT with the aim of improving the living conditions of the people living in slums.

During the process the problems of the slum were identified by an external agent (UN) and the community affected by the problems did not actually take part in the planning process; therefore, there was only a low level of social participation, namely informing. Consequently, in the case of KENSUP we can talk about external or expert-led planning. 
The developmental intervention was complex, mainly including infrastructure elements and focusing on the question of housing. As a result of the project, new residential buildings were constructed (Anderson and Mwelu, 2013), but their maintenance and preservation is questionable. In terms of the economic and labor market dimensions, KENSUP did not manage to offer an efficient solution for the affected parties; moreover, the large-scale construction works reacting to the housing issue increase the housing expenses, so the sustainability of the final result, primarily from an economic perspective, is questionable.

The social effect of the project in the longer term is also rather negative. The increasing housing expenses and the lack of additional income are expected to worsen the state of the new apartments to the level of the other parts of the slum after a while, because there are insufficient funds for the maintenance and potential development of the properties. Although in this case we can observe some improvement in infrastructural terms -because new stone houses are better homes even in a bad condition than tin-roofed mud huts -, the breaking up of local community due to the moving apart might result in much more negative social and economic effects than the project managers might have even thought about before.

The implementation of the program can be interpreted as a kind of "alien element" because it was not an integral part of the local area development and arrangement system. Therefore, following the program's conclusion, there seems to be no guarantee from local authorities in terms of continued appropriate operation and maintenance, such as subsidized housing or a system of social housing. This means that after the external agent leaves, the development is likely to get under the influence of the local political and market conditions, which will in all likelihood result in processes not favorable to the poor.

In the case of BiP:PUP, the following can be concluded: the program was initiated by an external agent, DFID, with the aim of making the existing planning mechanism of the public administration system more efficient and thus improving the conditions of the people living in the slums.

The planning process was carried out with the active involvement of the relevant community; that is, the level of social participation was partnership: the community defined the existing problems and elaborated the solution proposals. Therefore, we can talk about community planning.

The program was integrated into the Kenyan public administration system and the statutory requirements were efficiently exploited, which means that BiP:PUP did not set up a new system but figured out the way the existing framework can be operated efficiently. This way long-term sustainability is ensured within the political context. 
The intervention was complex, including infrastructure elements among others. As part of BiP:PUP, various training sessions aiming to improve hygiene, health and labor market conditions were organized (Chege, 2006). However, people acquired similar or even more important abilities and knowledge during planning and implementation, because they got an insight into the operation and planning mechanism of the public administrational system, and they learnt to express their needs in a multi-agent system and find a solution to them based on their resources, in cooperation with external agents and each other (Lyons et al., 2006).

As well as the capacities of the local communities, the program also managed to mobilize the resources of the market agents, which considerably decreases the costs for the local and central management. Decision-makers are therefore interested in applying the methods of the program more extensively and in the longer term.

Consequently, the results are more sustainable in social, economic, political and environmental terms. The program's long-term social effects are positive, since it has led to an active community that is able to act for its own prosperity.

Making an assessment on the basis of the aspects of comparison, we can establish that BiP:PUP realized with community planning definitely appears to be better and more efficient than KENSUP implemented with external planning, as it offered a sustainable solution to the actual problems defined by the local community, with the active participation of the people affected.

The Kitale program can be considered successful not only from the perspective of the local inhabitants, but it has also generated favorable effects for the local authorities and the central decision-makers. In the context of international development cooperation, it can be stated that the program has appropriately utilized the donors' resources - money, time and expertise - and has offered an optimal solution to the recipients too, since, on the one hand, interventions reacting to the actual demands were carried out, and, on the other hand, the developments launched long-term processes in the local community that made it flourish after the donors left.

At the same time, a weakness of BiP:PUP is that its results are not spectacular. The political agents of either the donor organizations or the recipients are unable to demonstrate megainvestments or big figures, and neither party can say that it has managed to eliminate a slum. BiP:PUP is therefore unsuitable for political maneuvering. However, if the objective is not to obtain the highest tax amounts possible or maximize votes with populist tools, but to support the most fragile class of society, BiP:PUP has definitely proved that community involvement and the approach and method of community planning are suitable tools for this purpose. 
Czirják, R.

\section{CONCLUSION}

This paper compared the two methods of slum upgrading: traditional external or expert-led planning with community planning or internal planning, which is realized with the active involvement of the community. According to our hypothesis, the key to efficient slum upgrading is the active involvement of the community affected by the planning process, that is, community planning.

To examine this statement, after a theoretical introduction we presented and compared two Kenyan slum upgrading programs, KENSUP and BiP:PUP. The procedure we considered successful was the one that offered a real solution to the problems defined by the local community and was sustainable both in economic and political terms, meaning the invested resources could be utilized appropriately.

The findings of the research show that the successful procedure was BiP:PUP, implemented with community planning. This is because the active involvement of the affected parties helped the agents find solutions to the pressing problems, and the procedure has induced long-term social processes enabling the local community to act for its prosperity even after their donors' departure.

However, it has to be mentioned that pre-conditions are necessary for successful community planning, which this paper does not cover. Although BiP:PUP is a good example, further investigation is necessary to explore what social, cultural, historical, etc. factors determine the success of social mobilization and participation. The author's aim is to deepen research in this direction.

Although BiP:PUP is considered a successful development, its achievements might seem to be only a drop in the ocean compared to the scale of the core problem, urbanization crisis. Eliminating slums from one day to the next is not a realistic aim, because almost 1 billion people can only be lifted from insufficient living conditions after the elimination of the mechanisms generating slums. However, considering the relations of inequality in the global economic system, unfortunately this seems to be a naïve objective. This recognition, however, must not make the part of society that is willing and able to help apathetic. After all, the societal participatory processes aiming to activate local communities are tiny steps that can slowly but surely improve the living conditions of more and more people. 


\section{REFERENCES}

Anderson, M., \& Mwelu, K. (2013). Kenyan slum upgrading programs: KISIP \& KENSUP [Pdf]. Retrieved from http://healthycities.berkeley.edu/uploads/1/2/6/1/12619988/kenya.pdf

Bardóczi, S., \& Giczey, P. (Eds.) (2010). Kézikönyv a részvételi városmegújításról. Budapest: Közösségfejlesztők Egyesülete Városmegújító Munkacsoport.

Beke, Z. F., \& Jávor, B. (2013). Résztvevők és apatikusak. Adalékok a társadalmi részvétel helyzetéhez Magyarországon. Politikatudományi Szemle, 22(4), 59-89.

Ciurlik, A. (2013). Participatory Development - should it be saved? Independent study project in Developmet Studies, 36.

Chege, P., \& Majale, M. (2005). Participatory Urban Planning in Kitale, Kenya [Pdf]. Retrieved from http://www.irbnet.de/daten/iconda/CIB1001.pdf

Chege, P. (2006). Participatory Urban Planning and Partnerships Building: Supporting Provision of Access to Basic Services for the Urban Poor: A Case Study Based on Practical Action's (ITDG) Experiences in Kitale, a Secondary Town in Kenya. p 15. [Pdf] Retrieved from https://www.fig.net/resources/proceedings/fig_proceedings/accra/papers/ts18/ts18_04_c hege.pdf

Czirják R. (2017). A közösségek szerepe a nemzetközi segélyezésben, kenyai nyomornegyedfejlesztések példáján. Budapest: ELTE TáTK, Közösségi és civil tanulmányok szak, szakdolgozat.

Davis, M. (2006). Planet of Slums. New York: Verso-New Left Books.

ITDG http://web.mit.edu/urbanupgrading/upgrading/resources/organizations/IT.html

Jeffrey, P. (2003). Participative planning and ICT tools; identifying and evaluating the benefits [Pdf]. Retrieved from http://econference.pict.hu/papers/11/Jeffrey\%20\%20Participative\%20planning\%20and\%20ICT\%20tools.pdf

Jones, L. (2015). Kibera upgrading project full of contradictions [Html]. Retrieved from http://www.nation.co.ke/lifestyle/DN2/Kibera-upgrading-project-full-of-contradictions//957860/2764288/-/15m83nrz/-/index.html

Keserü, D. (2010). Fenntartható állapotok?! - Az urbanizáció Afrikában. In I. Tarrósy (Ed.), Fenntartható Afrika (pp. 55-74). Pécs: Publikon Kiadó.

Kovács, Z. (2002). Népesség- és településföldrajz. Budapest: ELTE Eötvös Kiadó.

Lyons, M., Majale, M., \& Chege, P. (2006). Creating sustainable local economic development through sustainable partnerships: The BiP:PUP process in Kitale, Kenya. In E. Shragge, $\&$ M. Toye (Eds.), Community economic development: Building for social change. (pp. 264-278). Sydney: Cape Breton University Press.

MacPherson, L. (2013). Participatory Approaches to Slum Upgrading and Poverty Reduction in African Cities. Hydra - Interdisciplinary Journal of Social Sciences, 1(1), 85-95.

Majale, M. (2008). Employment creation through participatory urban planning and slum upgrading: The case of Kitale, Kenya. Habitat International, 32(2), 270-282.

Majale, M. (2009). Developing Participatory Planning Practices in Kitale, Kenya. Planning Sustainable Cities: Global Report on Human Settlements 2009, UN-HABITAT, p. 16. [Pdf]. Retrieved from https://unhabitat.org/wpcontent/uploads/2010/07/GRHS2009CaseStudyChapter04Kitale.pdf

Minja, D. (2017). Conversation with David Minja, Professor at Kenyatta University

MKP (2018). Map Kibera Project - Maps and Statistics [Html]. Retrieved from: http://mapkiberaproject.yolasite.com/maps-and-statistics.php

OECD (2005). The Paris Declaration on Aid Effectiveness [Pdf]. Retrieved from https://www.oecd.org/dac/effectiveness/34428351.pdf

Paragi, B., Szent-Iványi, B., \& Vári, S. (2007). Nemzetközi fejlesztési segélyezés tankönyv. Budapest: TeTT Consult Kft. 
Paul, S. (1989). Poverty Alleviation and Participation: The Case for Government-Grassroots Agency Collaboration. Economic and Political Weekly, 24(2), 100-106.

Ricz, J. (2009). Nyomornegyedek, szegénység, bünözés - van-e kiút? Falu-Város-Régió, 2, 26-33.

Sain, M. (2010). Területfejlesztési füzetek 1. szám: Segédlet a közösségi tervezéshez. Budapest: Nemzeti Fejlesztési és Gazdasági Minisztérium Területfejlesztési és Építésügyi Szakállamtitkársága (TÉSZÁT).

Scruggs, G. (2015). Turning Kibera's mud huts into apartment towers [Html]. Retrieved from http://citiscope.org/story/2015/turning-kiberas-mud-huts-apartment-towers

Solymári, D. (2012). A nyomor ezer arca - Elfeledett milliók [Html]. Retrieved from http://ujember.hu/a-nyomor-ezer-arca/

SURE (2012). Community Planning Toolkit [Pdf]. Retrieved from http://urbact.eu/sites/default/files/import/Projects/SURE/outputs_media/SURE_Toolkit_ participative_planning_HU.pdf

Szent-Iványi, B. (2009). A nemzetközi fejlesztési segélyezés hatékonysága. Ph.D. dissertation, Budapest, 266.

UN-HABITAT (2007a). Financing for the urban poor. Habitat Debate, 13(1), 1-24.

UN-HABITAT (2007b). UN-HABITAT and the Kenya Slum Upgrading Programme. Nairobi: UN-HABITAT.

UN-HABITAT (2008). UN-HABITAT and the Kenya slum upgrading programme - Strategy Document. Nairobi: UN-HABITAT. Retrieved from https://unhabitat.org/books/unhabitat-and-the-kenya-slum-upgrading-programme-strategy-document/

UN-HABITAT (2010). The State of African Cities - Governance, Inequality and Urban Land Markets. Nairobi: UN-HABITAT.

UN-HABITAT (2016). Urbanization and development: emerging futures. World Cities Report 2016. Nairobi: UN-HABITAT.

Warah, R. (2007). Élet Kiberában. In A világ helyzete 2007 - Városaink jövője - A Wordwatch Institute jelentése a fenntartható társadalomhoz vezetö folyamatról. Budapest: Worldwatch Institute, Föld Napja Alapítvány.

WUP (2014). World Urbanization Prospect: The 2014 Revision. United Nations, Department of Economic and Social Affairs, Population Division [Html]. Retrieved from https://population.un.org/wup/

WUP (2018). World Urbanization Prospect: The 2018 Revision. United Nations, Department of Economic and Social Affairs, Population Division [Html]. Retrieved from https://esa.un.org/unpd/wup/Download/ 